\title{
Getting real about food prices
}

\author{
Andrew Dorward \\ Forthcoming (after further editing): Development Policy Review (2011) \\ Email: Andrew.Dorward@soas.ac.uk \\ Web page: http://www.soas.ac.uk/staff/staff37115.php
}

\author{
Centre for Development, Environment and Policy \\ School of Oriental and African Studies \\ University of London \\ Thornhaugh Street, \\ Russell Square, \\ London WC1H OXG
}

UK

Future Agricultures Consortium

http://www.future-agricultures.org/

Elva Bova and Susan Newman provided valuable research assistance in the preparation of this paper. I am grateful to Colin Poulton, Peter Hazell, anonymous reviewers and particularly Julia Compton for helpful comments on earlier drafts. Any errors remain my responsibility. 


\title{
Getting real about food prices
}

\begin{abstract}
The 2008 price spike in world grain prices had serious impacts on food security and poverty but analysts have consistently described these real food prices as low in historical terms. The inconsistency between the severity of the food crisis and low real prices results from the use of advanced and global economy price indices to calculate real prices. This ignores the high share of food in poor people's expenditures and indirect effects of income growth on expenditure patterns of rich and poor consumers. Poor consumers have not experienced the same falls in real food prices as those with growing incomes and are more vulnerable to price shocks. As high and fluctuating international grain prices appear to be a feature of the current world economy, food price and policy analysis must recognise this, and develop and use different price indices that take account of differences between consumer groups.
\end{abstract}

Key words: food prices; food policy; price indices; food security, poverty 


\section{Getting real about food prices}

\section{Introduction}

During 2007 and 2008 grain commodity prices rose dramatically, peaking in mid 2008 with rice prices nearly tripling in 'real terms' (relative to the US CPI) in 12 months, wheat prices doubling, and maize prices nearly doubling. Coming on top of a more gentle halting and reversal (from 2002) of the widely recognised long term trend of falling 'real' international prices, the $2007 / 8$ price spikes provoked widespread fears of a food crisis, in terms of both immediate increases in the number of hungry and food insecure people and fears of a systemic change in the balance between food supply and demand (see for example Evans, 2009; Koning and van Ittersum, 2009; and Godfray et al, 2010a). The price spike led to riots and political unrest in a number of countries, and a world food summit in Rome in June 2008 (with another in November 2009). Although prices then fell dramatically in late 2008 , continuing higher and more unstable international prices (as compared with pre-2007 prices) and high food prices and shortages in some countries have led to a resurgence of both short and long term fears about food supplies and access (PREM, 2010). Food shortages and food insecurity continue to fuel widespread media interest, international and national policy initiatives and investments, and concerns about access to agricultural land (see for example The Economist, 2009 and 2010; World Summit on Food Security, 2009; Financial Times, 2010 and 2011; OECD-FAO, 2010; Deininger and Byerlee, 2011; ). These fears are particularly worrying in the context of likely negative effects of climate change on agriculture in many developing countries (despite possible medium term increases in productivity in temperate grain producing areas - see for example Easterling et al., 2007), increasing water scarcity and pressures on irrigation, continuing global population growth with rapidly rising populations in many poorer countries, and estimates of rising real food prices in the future, with increases in grain prices exacerbated by climate change (Nelson et al., 2009, for example, estimate grain price increases of 40 to $70 \%$ by 2050 without climate change, varying between grains, and by 90 to $190 \%$ with climate change).

The relative importance of various components of the 'perfect storm' behind the $2007 / 8$ price spike have been widely discussed, as have the damaging short and long term impacts of high food prices and the need for different short and long term responses (see for example Banse et al, 2008; OECD, 2008; Von Braun, 2008; FAO, 2009; Piesse and Thirtle, 2009; Toye, 2009; Headey and Fan, 2010). All these references are typical of many other similar reports in placing the $2007 / 8$ price spike in a historical context, comparing it with the 1974 price spike and noting that despite the severity of the $2007 / 8$ price spike, grain prices in 2008 were, even at their peak, considerably lower in 'real terms' than in 1974, and indeed were not much higher than prices at various times in the late 1980's to mid 1990's (see figure 1, or FAO, 2009 p13, or Von Braun, 2008 p3). Thus, for example, Piesse and Thirtle state that 'The historical background shows that the price spike was much less severe than in the 1970s' (Piesse et al., 2009, p 119) and FAO, 2009 state that "At 2000 prices and exchange rates ... the cost of one tonne of rice in 1974 stood at well over four times the average over the first four months of 2008" (p12 ${ }^{1}$ ). Taking a longer term view, figure 1 also shows that real wheat prices (relative to the US CPI) at their peak in 2008 were considerably lower than prices that prevailed prior to the mid 1960s (apart from two brief periods of low prices in the 1930s) and Von Braun, 2008

\footnotetext{
${ }^{1}$ FAO, 2009 uses the World Bank's Manufactures Unit Value Index (MUV) as the deflator but this faces similar difficulties as those described in this paper for the US CPI.
} 
notes that "... current prices are not particularly high in historical terms.." ( p3). Indeed, Godfray et al (2010b) open their abstract with the statement that "Although food prices in major world markets are at or near a historical low, there is increasing concern about food security-the ability of the world to provide healthy and environmentally sustainable diets for all its peoples." The seriousness of the 2008 price hike is then seen as serious not so much for the historically high prices experienced but in terms of (a) its effects on poor people, (b) the existence and dangers of price instability, and (c) the indications it provides of potentially increasing threats to food supplies (particularly for the poor) from climate change, climate change responses, water shortages, land degradation, the increasing global populations, and increasing demand for grain for animal production. This does, however, pose questions about the meaning and spread of prices which, despite short term increases are still supposed to be low by historical standards.

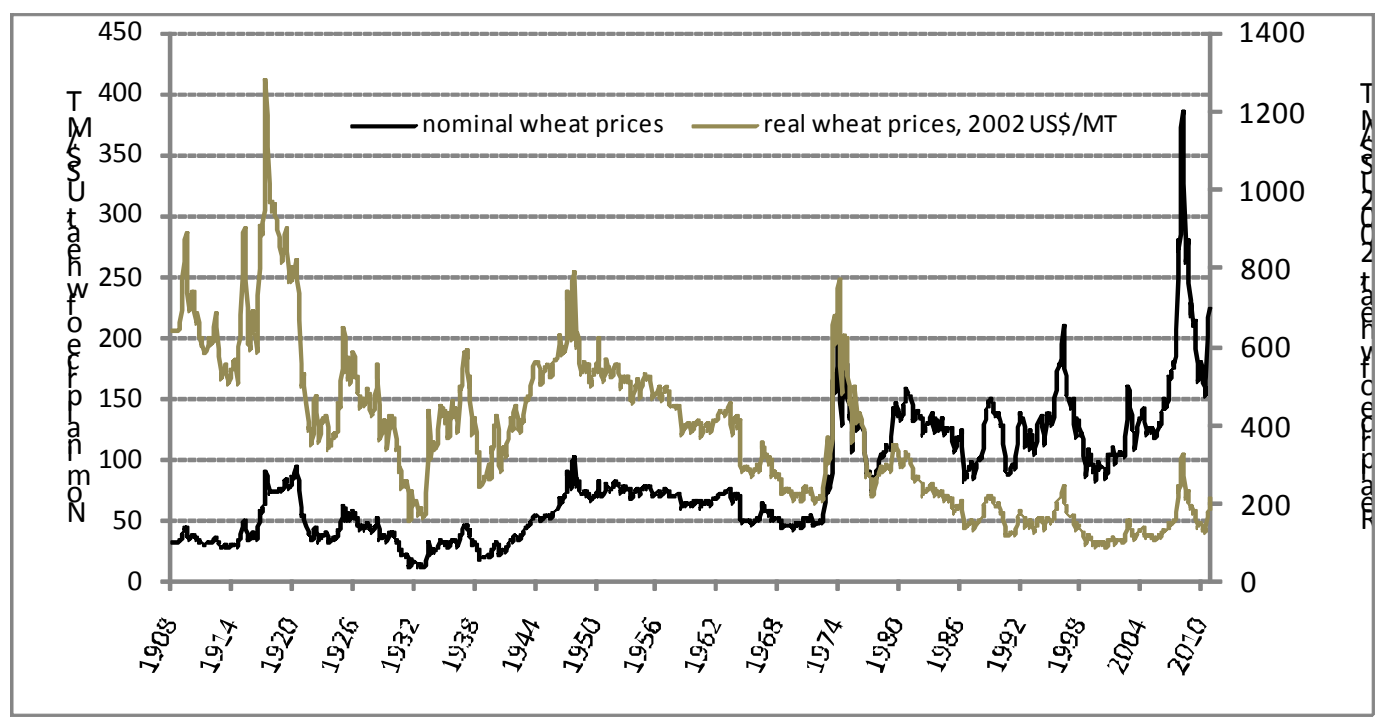

Figure 1. Nominal and real wheat Prices in the US 1908-2010

This paper investigates this discrepancy between statements recognising the severity of the food crisis of 2007/8 on the one hand and the perception that real food (basic grain) prices were nevertheless low in historical terms. It is suggested that these are not compatible, and that one of these perceptions must be wrong. We show that the perception of historically low real food prices is an artefact that results from the widespread use of the US CPI as the real price deflator. We argue that real food prices so defined are indeed historically low for rich countries, and falls in real food prices are an inevitable and intrinsic component of economic growth. Nevertheless rich country

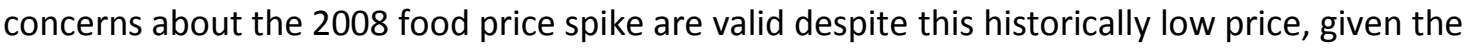
context of wider concerns about their presaging future global food shortages as discussed above. For poor economies and particularly for poorer people within those economies, however, real food prices have fallen less than this analysis suggests, in two ways. First, the use of the US CPI (and other commonly used global CPIs) lowers food prices relative to non-food prices more than is actually experienced by poor people: this is an intrinsic and inevitable result of structural changes that accompany income growth. Second, much of the discussion about food price changes is implicitly if

\footnotetext{
${ }^{2}$ All Wheat US season average price, Table 20 from USDA (2010); price index calculated from David and Solar, 1977 and US Bureau of Labour Statistics (2010).
} 
not explicitly about their impacts on people's welfare, but welfare impacts of these changes are not measured by calculating 'real' food prices relative to non-food prices but by calculating 'real' food prices relative to income - and in these terms falling real food prices (and non-food prices) are an intrinsic component of income growth while continuing high food and non-food prices are an intrinsic component of poverty. International agencies such as FAO, IFPRI, DFID and the World Bank concerned with poor and food insecure people should therefore not be stating that the 2008 food price spike did not lead to historically high prices (op. cit.) - or least they should not make such statements without clear and strong qualifications.

More generally, more care needs to be taken in the choice and use of measures of food prices in framing debates and in analysis of changing world food prices. Such debate and analysis needs to explicitly recognise that 'real prices' can be defined in different ways (relative to CPI or incomes for example) and that different measures of real prices have different strengths and weaknesses in different uses and different situations (and this is not making things particularly or unnecessarily complex: it is very important for policy and not just an academic exercise). Similarly, changes in real prices (relative to $\mathrm{CPI}$ ) differ between economies not just as a result of transport and other costs and information failures separating markets, they also differ between economies as a result of differences in income and wealth ${ }^{3}$. Recognition of these arguments shows that the 2008 food price spike did lead to historically high food prices for the poor, and this, critically, strengthens arguments about the seriousness of the global food situation.

Following this introduction, we examine in the next section problems posed by inflation and outline the common use of real price relative to $C P I$ to describe changes in real food prices, and potential problems associated with this. In the following section we show that there is a downward bias in estimated real food price changes for low income groups when these are calculated using a CPI calculated for higher income groups. The theoretical argument is illustrated with empirical data in the following section of the paper. The paper then argues that even once this bias is corrected, real price relative to $\mathrm{CPI}$ is not the best measure of food price changes when considering their impact on poor people. It concludes with policy recommendations regarding use of better measures of real food price changes and the implications of under-estimating the scale of recent increases in real food prices.

\section{Real prices relative to CPI}

Analysis of real, rather than nominal, price changes over time is necessary because inflation, which affects most economies most of the time, erodes the value of money. This causes nominal prices to rise. Although different inflationary effects on the values of different types of goods and assets and on incomes from supplying and using different goods, services and assets may lead to some changes in relative prices, it is reasonable to describe inflation (i) in terms of an average increase in prices, with $P_{j t}=\left(1+i_{t}\right) P_{j t-1}$ for all goods and services, $j$. Average prices are calculated using the Consumer Price Index (CPI), with prices weighted by expenditure shares (see annex 1 equations 1 and 2).

\footnotetext{
${ }^{3}$ Such differences are of course recognised implicitly in food security and poverty analysis and policy. Our argument is that they need more explicit recognition.
} 
Annual inflation is then calculated as $I_{t}=C P I_{t} / C P I_{t-1}$ and the real price of a good or service $j$ at time $t$ in constant prices for $t=0$ is then given by $\boldsymbol{P}_{j t}=P_{j t} / C P I_{t}$.

This equation (or others using similar price indices) is widely used to calculate 'real prices', but the real price is more accurately described as the ratio of price for particular goods and services to the prices of other goods and services, or 'real price relative to CPI'. It should be noted that it takes no account of changes in incomes and provides no information about welfare changes. This does not pose a problem (a) when it is being used to examine the effects of general price inflation on real incomes, (b) over periods when real incomes have not changed very much, (c) where percentage changes in prices of different goods and services are broadly similar, or (d) where goods and services which experience large price changes have a small share in expenditures and a small weight in the calculation of the CPI.

Unfortunately, none of these conditions hold when using 'real price relative to CPI' to consider the welfare implications of long term changes or short term spikes in real food prices in the context of different groups' diverse experiences of economic and income growth. The fundamental difficulty here is that indexing with the CPI provides no comparison with changes in incomes. The use of 'real price relative to $\mathrm{CPI}^{\prime}$ in this context can, therefore, be highly misleading. Particular problems arise first where low and high income groups have different sets of high expenditure goods and services (for example basic foods account for a higher proportion of expenditure amongst low income groups), and second in the way that it under-estimates the welfare (or real income) impact of change in price of high expenditure goods and services (as the effect of these price changes on the $\mathrm{CPI}$ is dampened by the large effects of the same price change on the denominator in the CPI calculation).

It is therefore unfortunate that real prices relative to CPI are so often used in discussions of food price change impacts on the poor (as demonstrated earlier) without consideration of these issues. We now consider in more detail the nature of the errors that result from this.

\section{Bias in estimates of real food prices relative to CPI}

In order to examine possible bias in estimates of real food prices relative to $\mathrm{CPI}$, we start by the simple recognition (a) that changes in relative prices of different purchased goods and services are caused by changes in the balance of supply and demand of these goods and services, and (b) that supply and demand are affected by both short term shocks and variation and by longer term trends affecting production costs relative to consumer purchasing power and preferences. It is these longer term trends that are initially of interest to us, in particular those associated with economic and income growth.

A growing economy is characterised by increases in productivity which should both directly lead to increased supply from lower production costs and indirectly increase demand as a result of increasing incomes. Supply and demand will however increase at different rates for different goods and services, depending upon the extent of productivity increases for different goods and services, the rate of income increase, and the income elasticity of demand for these goods and services. 
These will then interact with trade opportunities for the same goods and services to determine changes in their price.

We explore this by tracing out what happens in a poor closed economy to relative prices for two sets of goods and services where the first set (F) accounts for a substantial share of consumer expenditure and has low price and income elasticities of demand and the second set (G) accounts for a small share of consumer expenditure and has high price and income elasticities of demand.

Starting from this initial situation, we explore the effects of technical and institutional changes that increase labour productivity in the production of good $F$ (see for example Johnston and Mellor, 1961 with regard to agriculture, and some of these effects are also important in the Prebish-Singer thesis - see for example Kaplinsky, 2006). With price inelasticity of demand, increased productivity for good $\mathrm{F}$ leads to a falling price of $\mathrm{F}$. This in turn leads to rising real income (this does not put significant upward pressure on the price of $\mathrm{F}$ due to its low income elasticity of demand). These productivity, price and real income changes will (under favourable conditions) be accompanied by complementary structural changes in both income and expenditure patterns:

- Wages in the production of $\mathrm{F}$ will experience a downward pressure as a result of falling prices for $F$, but upward pressure as a result of higher labour productivity. The former will normally prevail if there is no movement of labour out of production of $F$.

- However demand for and expenditure on $\mathrm{G}$ will rise as a result of the higher real incomes (from falling prices of $F$ ). Prices of $G$ will then rise, leading to increasing wages and income in production of $\mathrm{G}$.

- Labour should then move from production of $F$ to production of $G$, until labour wage rates from the two sectors are equal ${ }^{4}$.

- The outcomes of these different processes are higher wages and incomes, lower prices of $F$ relative to both incomes and prices of $\mathrm{G}$, and a fall in the proportion of expenditure on (and income from) $F$.

- At these higher incomes there will be goods and services (or groups of goods and services) that were previously classified as $\mathrm{G}$ (high price and income elasticity of demand) that now have lower price and income elasticity of demand - and should therefore be reclassified as $F^{\prime}$, with the original set of goods and services $F$. The original set of goods and services $F$ are then of diminished importance in incomes, expenditures and the economy within $F^{\prime}$, the expanded set of goods and services with lower price and income elasticity of demand. At the same time as some goods and services with lower price and income elasticity goods and services in set $\mathrm{G}$ will have moved to $\mathrm{F}^{\prime}$, the remaining members of set $\mathrm{G}$ will be joined in a new set $G^{\prime}$ by new higher income and price elasticity goods and services which have become affordable with new technologies and/or with higher incomes.

- The process of development involves a continual process of productivity growth in both high and low price and income elasticity goods and services, and a constant redefinition of sets $\mathrm{F}$

\footnotetext{
${ }^{4}$ Structural difficulties limiting this often lead to lower agricultural and rural wages and are a significant cause of agricultural subsidy policies in middle and upper income countries.
} 
and $G$, with shifts of goods and services from set $G$ to set $F$, new goods and services entering set $G$, and a constant decrease in the relative importance of goods and services that have entered (or were part of) set $F$ at early stages of economic development.

Basic or staple foods fall into this latter category of goods and services as a major part of set $F$ in poor economies with low incomes and wage rates at early stages of economic development ${ }^{5}$.

Three simple and well known stylised facts emerge from this analysis:

- First, the composition of non-food expenditures changes with peoples' and economies' increasing incomes.

- Second, the importance of basic foods in expenditure patterns declines with peoples' and economies' increasing incomes.

- Third, with increasing incomes the price of basic foods falls relative to the price of goods and services with higher income and price elasticities.

These stylised facts mean that the expenditure baskets of consumers change as their incomes rise: first the importance of food is greater in the CPI of poorer people, and second the composition of non-food expenditures is different. This means that the expenditure baskets of rich and poor people and economies differ considerably. It also poses difficulties for the calculation of the CPI as defined in equations (1) and (2) in the appendix.

Equations 5 to 9 and the associated text in the appendix set out the standard re-indexing method for adjusting the calculation of the CPI to allow for changes in consumers' expenditure baskets over time. However, the re-indexing of the CPI should lead to different estimates of real food prices if CPI is estimated separately for people with growing (and hence high) incomes and for people with stagnant (and low) incomes.

Two effects of differences in expenditure shares are important.

First the high share of food in poorer people's expenditure basket dampens the effects of nominal food price changes on real food prices. This arises because there are large changes in the denominator as well as in the numerator in the calculation of real food prices. We term this the 'denominator effect': it is not explicitly demonstrated in the appendix but should be evident from equations 1, 2 and 4. It dampens the estimated extent both of long term falls and of short term

\footnotetext{
${ }^{5}$ Low income and price elasticity for basic foods are widely recognised. Declining expenditure shares on basic foods as incomes increase are the basis of Engel's Law. At one extreme, Lipton's definition of ultra-poverty is spending $80 \%$ or more of income on food and consuming $80 \%$ or less of energy needs (Lipton, 1986). The poor are widely recognised as spending 50 to $70 \%$ of their income on food (Von Braun, 2008), while in the US median expenditure share of food in 2007 was just under 13\% (Crawford and Katz, 2009) - and within this there are significant expenditures on higher value 'non-basic ' livestock products, processed foods, 'decommodified' brands and food services.
} 
spikes in real food prices relative to low income group CPI when compared with the estimation of changes in real food prices relative to higher income group CPI.

Second, the expenditure baskets for groups with rising (and hence higher) income change more than for groups with stagnant, low incomes not only as regards increasing importance of non food expenditure, but also in the nature of that non-food expenditure. The prices of higher income groups' non-food expenditure tend to rise relative to food prices (which dominate the CPI calculation for low income groups). This in turn leads to the CPI of higher income groups rising faster than that of lower income groups, and this causes larger falls in real food prices (relative to CPI) for higher income groups. We term this (demonstrated in equations 10 to 17 and associated text in the appendix) 'the non-food basket effect'.

It is important to note that both the denominator and non-food basket effects occur even if the two groups face the same nominal prices ${ }^{6}$, and this provides an important explanation for the discrepancy observed at the beginning of this paper, between on the one hand recognition of the severity of the 2008 food price spike but on the other observations that real food prices relative to $\mathrm{CPI}$ were not high by historical standards. This is because in wider discussion of global food prices, real food prices relative to CPI are generally calculated using the US CPI. The US has over the last 100 years experienced dramatic income growth. This means that analysis of global changes in real food prices relative to $\mathrm{CPI}$ (i.e. real food prices relative to $\mathrm{CPI}$ ) is generally being conducted using the $\mathrm{CPI}$ for a very high income group. This leads to overestimates of falls in real food prices relative to CPI for low income groups ${ }^{7}$.

Empirical analysis of the extent of this overestimate is not easy, as it requires calculation of separate CPIs for low and high income groups for a considerable period of time. Ideally differences between low and high income real food prices could be empirically demonstrated by comparing changes in real food prices calculated with CPI for low income groups or countries against changes in real food prices calculated with US CPI. This would need to separate out the effects (and causes) of exchange rate fluctuations, of different changes in nominal prices, and of different national markets' variable and partial integration into world markets. We have not thus far been able to obtain or construct such differentiated CPIs and in this paper present an argument for work to be undertaken to address these issues. .

Nevertheless a partial illustration of the effects of overestimation of the CPI of poorer people and of the historical fall in real food prices relative to CPI is provided in figure 2.This abstracts from problems of differences in nominal prices and exchange rates by comparing real wheat prices relative to US CPI from 1957 to 2008 with real prices relative to a stylised low income US CPI

\footnotetext{
${ }^{6}$ Note that discussion of real changes in international food prices usually considers price changes for basic commodities or for a food price index (such as the FAO food price index) dominated by basic commodities. Differences in the composition of food expenditure baskets for high and low income groups do not therefore affect nominal prices used in real price change estimates relative to CPI. They will, however, affect the CPI, with CPI for higher income groups including greater expenditures on higher value and processed foods (see for example OECD-FAO, 2010). This will lead to rises in nominal food prices for groups with rising incomes relative to groups with stagnant, lower incomes. This exacerbates the non-food basket effect.

${ }^{7}$ Similar arguments apply with the use of price indexes calculated from global commodity prices (for example World Bank's Manufactures Unit Value Index, MUV) since these are predominantly supplying consumption by higher income groups.
} 
calculated as $\left(0.7 \mathrm{CPI}_{\mathrm{F}}+0.3 \mathrm{CPI}\right)$ as the deflator for calculation of low income real food prices where $\mathrm{CPI}$ is the US all items city average consumer price index and $\mathrm{CPI}_{\mathrm{F}}$ is the world food price index ${ }^{8}$.

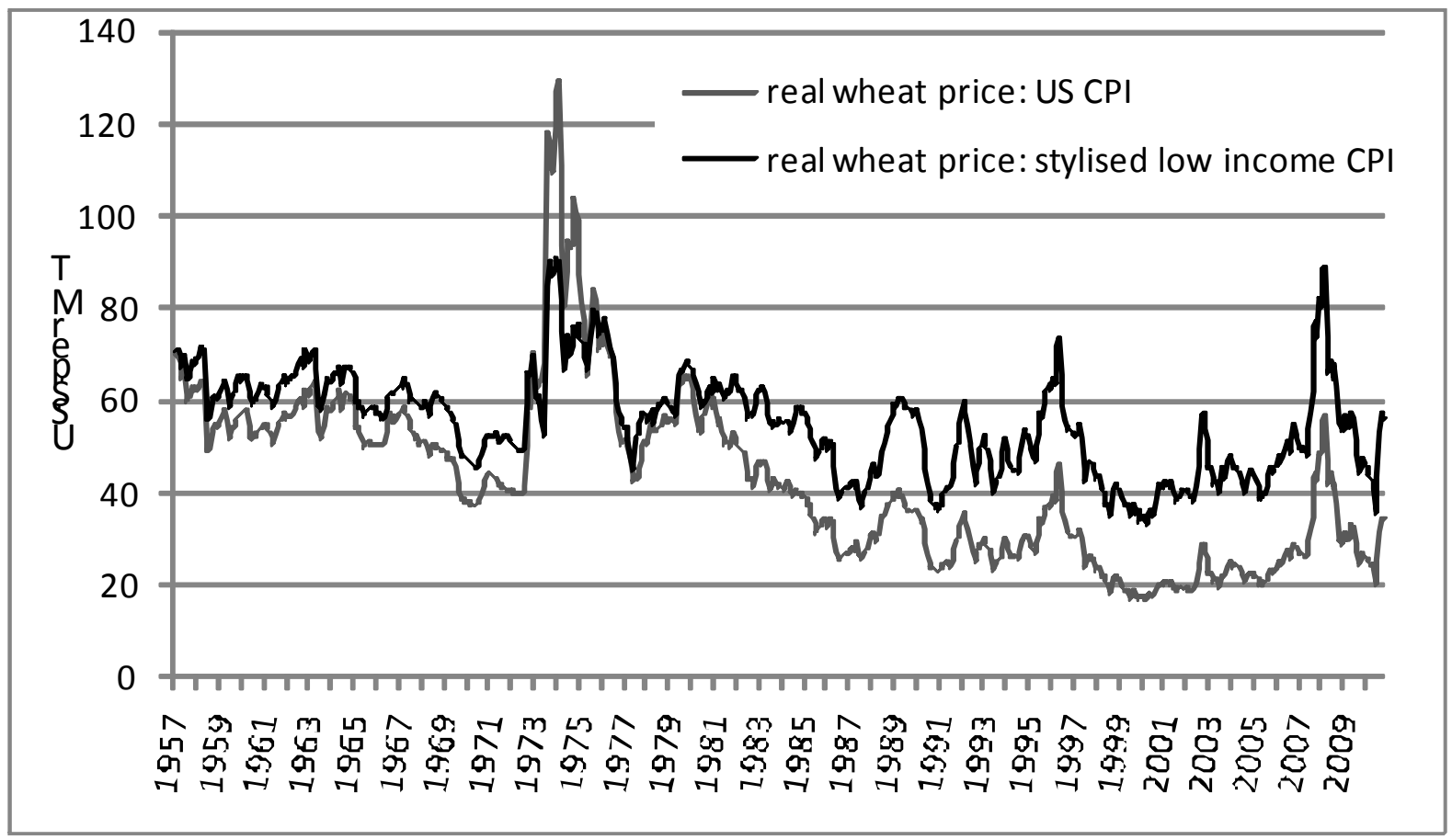

Figure 2. Wheat prices, nominal \& 1957 prices deflated with US \& stylised low income US CPI ${ }^{9}$

The results are striking, with a clear divergence between the real prices calculated with high and low income CPI. This is despite the limitations of the stylised CPI which under-estimates the bias in real food price relative to US CPI estimates for low income groups, as it only addresses one of the causes for such bias (the denominator effect, where the large food expenditure share damps real price changes). It does not allow for the lower fall in non-food prices experienced by those with stagnant incomes (the non-food basket effect). Despite this, real food prices relative to the stylised low income CPI show a much smaller secular decline in real food prices relative to CPI. As a result shorter term price variation is much more important, and the 2008 price spike is similar to the 1970 s price spikes and greater than the 1990s spike. These differences would be exacerbated if the nonfood basket effect were also allowed for ${ }^{10}$.

\footnotetext{
${ }^{8} \mathrm{CPI}$ and $\mathrm{CPI}_{\mathrm{F}}$ from IMF (2010), codes $11164 \mathrm{ZF}$ and 00176EXDZF respectively.

${ }^{9}$ Calculated from IMF (2010) as described in text and previous note with U.S. Gulf wheat prices (index 11176D.ZZF).

${ }^{10}$ Exchange rate changes might however have ameliorated this in some countries whose currencies appreciated against the dollar in the first half of 2008 (for example in Zambia, Jayne, pers. comm..) but not in others where the exchange rate held constant or fell against the dollar. Country specific relative changes in nominal food and non-food prices will have had country specific effects on relative food prices, though generally high fuel costs will have both raised non-food prices and the price of imported foods in landlocked countries.
} 


\section{Discussion}

A number of simple but nevertheless important observations and recommendations emerge from our demonstration that price indexes for growing and high income people and countries are higher than for people and countries with low, stagnant incomes.

First, it is not appropriate to use analysis of changes in real food prices relative to US CPI (or other advanced economy price indexes) when considering changes in real food prices for low income groups (countries or people), as in the publications cited earlier in the introduction. Statements about historically low food prices derived from price indexes from high or growing income countries are not relevant when discussing low income countries or groups. In the context of policy analysis and discussion regarding low income countries or people there should be no more general statements that real food prices are historically low relative to US (or other high income) CPI. There needs to be specific consideration of why 'real' food prices are being analysed, and different measures used depending on the focus of the analysis as regards (a) income characteristics (for example high or low) and (b) the purpose of the analysis (for example concern about relative prices of food, other commodities, goods, services and factors of production or concern about welfare impacts).

Second, and following from the first point above, greater emphasis and resources should be given to separate calculation of CPIs for low and high income groups (of people and countries). Separate calculations are done for the terms of trade for different countries and groups of countries in international trade analysis (for example UNCTAD, 2010) and a similar approach could be used for CPIs. This needs to be formally incorporated into analysis and discussion of changes in real food prices. This then requires data collection for and calculation of separate CPIs for low and high income groups within poorer economies ${ }^{11}$.

Third, and more fundamentally, real food prices relative to CPI are not the most appropriate measure to use in analysing the impact of long or short term food price changes on the welfare of (poor) income groups for whom food accounts for a significant share of expenditure. For such people food prices need to be compared to incomes. This involves examination of the terms of trade for countries (as mentioned earlier) and of food prices relative to income. ${ }^{12}$

Some indication of the effects of analysis of the latter point are provided in figure 3 , which compares real prices deflated with the US income (GDP) per capita (representing a high income group) against

\footnotetext{
${ }^{11}$ Examination of the differences in CPI between poor and wealthy households in more developed economies has tended to look at shorter periods with fixed expenditure patterns (see for example King, 1976; Blisard et al., 1999; Murphy and Garvey, 2004; Pike et al., 2008) and consequently neither high expenditure share bias nor changing composition of non-food expenditures are important, and only small differences are observed, reflecting short term changes in relative prices of food and non-food items. Raihan and Haque (2007) cited in Raihan (2009) argue that Bangladesh's official inflation statistics misrepresent inflation facing poor households to the extent that official $2007 / 8$ food inflation of $9 \%$ coincided with an increase in poor households' average food purchase expenditures s of around $20 \%$.

${ }^{12}$ This is a much less serious issue for high income groups whose real incomes are much less affected by food price rises.
} 
real prices deflated with Malawi income (GDP) per capita (representing a low income group) ${ }^{13}$. The comparison is interesting: from 1960 to 1980 the two sets of real wheat prices tended to move together as economic growth was similar in both countries. Thereafter, however, they diverge sharply as Malawi's income per capita fell relative to that of the US. Real wheat prices deflated by US GDP per capita dropped sharply after 1980 while those deflated by Malawi's GDP per capita remained much higher and more volatile. Then in 2009 and 2010 they begin to converge again as the Malawi economy grew faster than the US economy - even though Malawians are still considerably poorer than US citizens. ${ }^{14}$

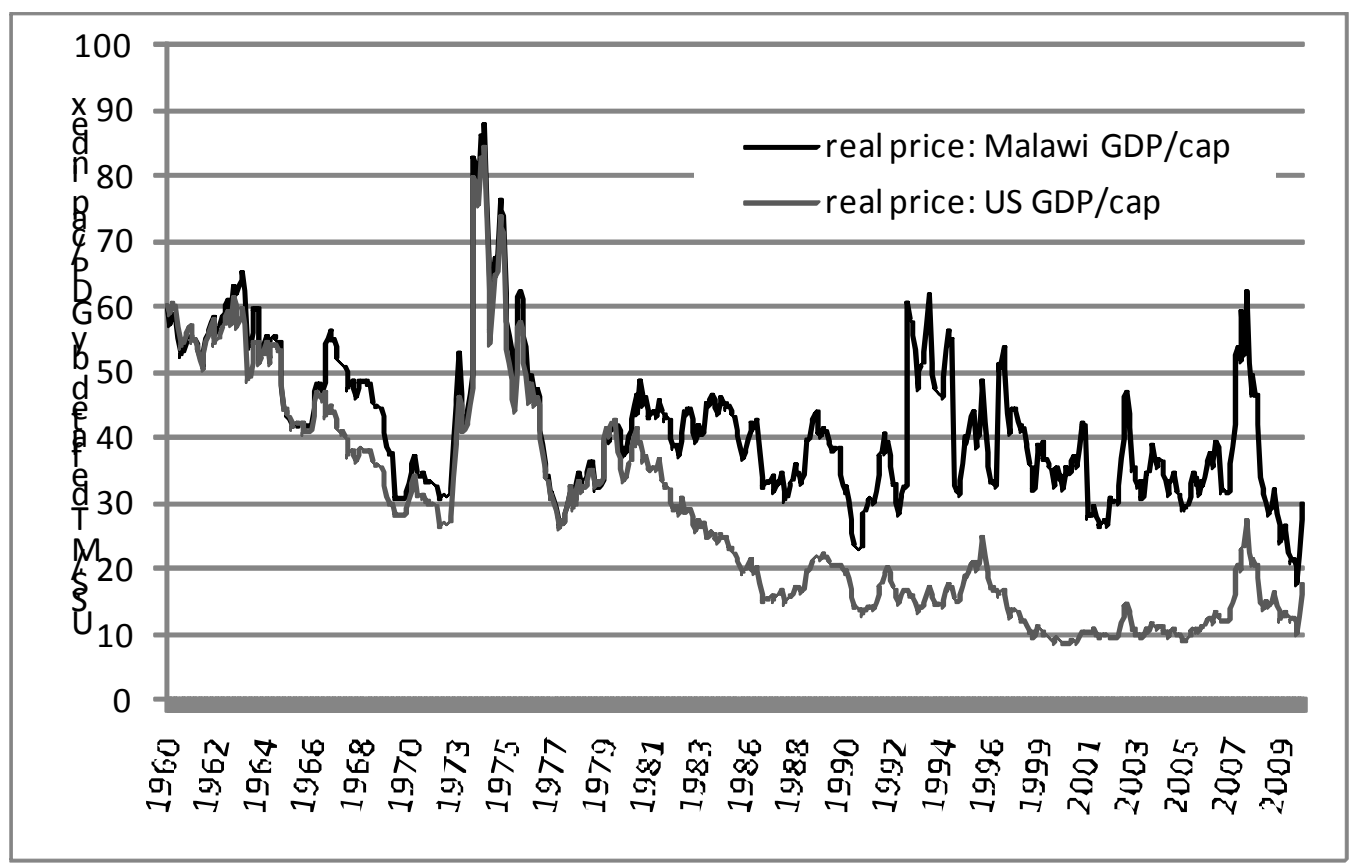

Figure 3. Real wheat prices deflated with US GDP/cap \& Malawi GDP/cap 1960 index, ${ }^{15}$

It is also interesting to note that the effect of the 2008 food price hike on real prices relative to GDP/capita in figure 3 is similar for the two measures of real prices as regards proportionate price increases. Real prices deflated by GDP per capital, however, underestimate the severity of the effects of high basic food expenditure shares for poor income groups for two reasons. First, as noted earlier, GDP per capita makes no allowance for income distribution, and skewed income distributions generally lead to much lower median incomes than suggested by mean GDP per capita. More fundamentally, however, it does not allow for the differential effects of food price rises on low income groups. This is shown in table 1 , which provides illustrative figures demonstrating how a $100 \%$ increase in the price of basic foods affects the total and non-basic food expenditures of

\footnotetext{
${ }^{13}$ GDP per capita in current US\$ is indexed to 1980 for both data sets.

${ }^{14}$ Where there is increasing income inequality with increasing GDP, as is likely to have been the case for example in Malawi from 1960 to 1980 with substantial income growth for a minority of the population driving much of the national GDP growth, then the fall in real prices relative to GDP will overstate the fall in real prices relative to median income - the omission of any consideration of income distribution is lack of any ${ }^{15}$ Wheat prices from IMF (2010) and GDP/capita from World Bank, 2010 (with extrapolation for 2009 and 2010).
} 
different income groups with different expenditure shares on basic foods ${ }^{16}$. The same basic food price rise relative to income therefore has widely differing impacts on real income and welfare for different income groups. This differential effect of basic food price changes on different income groups is not captured by analysis of real food prices relative to either CPI or income. Change in expenditure share on basic food may therefore be the best (but by no means perfect) measure of welfare impacts of changes in food prices (and indeed other prices).

Table 1. Illustrative effects of $\mathbf{1 0 0 \%}$ increase in staple food prices on total expenditures for high and low income households

\begin{tabular}{|l|c|c|c|c|}
\hline \multirow{2}{*}{ Income } & \multirow{2}{*}{$\begin{array}{c}\text { Initial \% } \\
\text { expenditure on } \\
\text { food }\end{array}$} & \multicolumn{3}{|c|}{$\begin{array}{c}\text { Results of 100\% food price rise with no adjustment in food } \\
\text { consumption but adjustments in non-food expenditure }\end{array}$} \\
\cline { 3 - 5 } & & $\begin{array}{c}\text { \% increase in total } \\
\text { expenditure }\end{array}$ & $\begin{array}{c}\text { \% change in non } \\
\text { food expenditure }\end{array}$ & $\begin{array}{c}\text { Final \% expenditure } \\
\text { on food }\end{array}$ \\
\hline Very high & 5 & 5 & -5 & 10 \\
\hline High & 10 & 10 & -11 & 20 \\
\hline Low & 30 & 30 & -43 & 60 \\
\hline Very low & 50 & 50 & -100 & 100 \\
\hline $\begin{array}{c}\text { Extremely } \\
\text { low }\end{array}$ & 70 & 70 & N/A & NA \\
\hline
\end{tabular}

\section{Conclusions}

This paper has argued that there is a discrepancy between perceptions of falling real food prices and the severity of the impacts of the 2008 food price spike for poor people and economies, and shown that this is the result of defining real food prices relative to the US CPI (or other global price indexes), because price indexes are higher for growing and high income people and countries than for people and countries with low, stagnant incomes. This leads to important questions about how we measure and interpret changes in real food prices (for example what do the food price predictions by Nelson et al cited at the beginning of the paper really mean?) and to recommendations regarding the way that changes in real food prices are analysed and reported.

Most obviously, the use of real food prices relative to US CPI (or other global price indexes) is misleading in discussion of changes in real food prices for poorer countries and for poorer income

\footnotetext{
${ }^{16}$ Table 1 assumes that priority is given to basic food purchases over other purchases, with no changes in basic food purchase composition (ie no substitution). This may not be strictly tenable in many circumstances, but does not affect the broad argument as options for changes and substitutions in food purchase composition are increasingly constrained as income declines. This means that higher income households have greater opportunities to reduce the effects of a rise in nominal food prices on their food expenditures by changing the composition of their food purchases to lower price alternatives, as compared with poor households already buying the cheapest types of food available and whose major response must be to reduce food consumption and/or non-food expenditures. See Jensen and Miller (2008) for discussion of such situations in the context of the effects of food price changes on different income groups and on the Giffen effect in two cities in China.
} 
groups within those countries. If this is the case, then alternative measures of changes in real food prices are needed. It is argued that choice of measures must be related to the use of the measure but choice of measure is also determined by data availability, costs of data collection and analysis, and the extent to which measures can be generalised - a great attraction in using real food prices relative to US CPI or other global price index is that it appears to be globally applicable, it is just unfortunate that it is not.

We conclude by proposing three alternative measures of real food price changes for use in analysis and discussion of food prices in poorer economies, each with different advantages and disadvantages depending upon data availability, situation, and purpose of analysis ${ }^{17}$ :

1. Real basic food price relative to a historical low income US CPI: this would involve the estimation of a CPI using expenditure shares from the US in the past, when the US was a low income country. This requires data and recalculation going back to, for example, the early 1900s. The advantage of this is that it overcomes the re-indexing and low basic food expenditure share bias inherent in the use of the current US CPI, but it nevertheless provides a globally applicable measure. There may, however, be data difficulties. The high food expenditure share in the CPI also means that the effects of food price shocks on poorer people's welfare is under-estimated (as a result of the denominator effect) and it has in any case been argued that CPI based measures do not perform well in capturing welfare impacts of food prices for poor people.

2. Real basic food price relative to income: this provides a good measure of changes in welfare associated with changes in food prices. However, as with the previous measure, though for different reasons, it does not provide a good indication of differences in welfare impact of food price shocks on low and high income groups. There are also likely to be difficulties with data and with coming up with a globally relevant low income measure ${ }^{18}$.

3. Basic food expenditure shares: this provides the best information about the effects of long and short term changes in food prices on both high and low income groups, and in these important respects it is the best measure of the three proposed here. As with the previous measure, however, there may difficulties with data and with development of a more generalised measure.

Further work is needed to develop and test the construction and application of each of these measures.

\footnotetext{
${ }^{17}$ None of the proposals address a further issue that arises from divergencies in exchange rates or in nominal prices: this could be addressed as more ad hoc additions to the analysis for situations where divergences are sufficiently large to need explicit consideration.

${ }^{18}$ Some measure of global low income GDP per capita may be appropriate here, but this will need to take account of distributional issues within countries, for example with some (for example Gini coefficient related) adjustment to GDP per capita to provide an estimate of median rather than mean income.
} 


\section{Appendix : Calculating real food prices relative to CPI}

Complications in calculating 'real prices' arise because the three different types of money price change (changes due to inflation, changes due to supply and demand shocks, and changes due to secular, structural trends in growing economies) interact in complex ways.

The standard calculation of real prices compares nominal prices against the nominal value of a particular bundle of goods and services at different times. The real value of that bundle is assumed to remain constant, so that any changes in the money value over time are due to changes in the value of money, i.e. inflation (or very rarely deflation). This system is formalised using a consumer price index (CPI) to track price changes over time:

$$
\mathrm{CPI}_{\mathrm{t}}=\sum\left(\mathrm{P}_{\mathrm{jt}} \mathrm{w}_{\mathrm{j} 0}\right) / \sum\left(\mathrm{P}_{\mathrm{j} 0} \mathrm{w}_{\mathrm{jo}}\right)
$$

where $w_{j 0}=P_{j 0} Q_{j 0} / \sum\left(P_{j 0} Q_{j 0}\right)$

$P_{j t}=$ nominal price of good or service $\mathrm{j}$ in year $\mathrm{t}$

$\mathrm{Q}_{\mathrm{jt}}=$ quantity purchased of good or service $\mathrm{j}$ in year $\mathrm{t}$

$\mathrm{w}_{\mathrm{j} 0}=$ weighting of expenditure on good or service $\mathrm{j}$ in base year $\mathrm{t}=0$ in a representative consumer 'expenditure basket'

$\sum\left(\mathrm{P}_{\mathrm{jt}} \mathrm{Q}_{\mathrm{jt}}\right)=$ total consumer expenditure in year $\mathrm{t}$ on goods or services $\mathrm{j}=1$ to $\mathrm{n}$

Annual inflation is then calculated as

$$
\mathrm{I}_{\mathrm{t}}=\mathrm{CPI}_{\mathrm{t}} / \mathrm{CPI}_{\mathrm{t}-1}
$$

The real price of a good or service $j$ at time $t$ in constant prices for $t=0$ is then given by

$$
\mathbf{P}_{\mathrm{jt}}=\mathrm{P}_{\mathrm{jt}} / \mathrm{CPI}_{\mathrm{t}}
$$

It is important (a) that the 'expenditure basket' of goods and services used should be representative of the way that money is used and has value in an economy and (b) that the bundle of goods and services should be standardised over time. Condition (a) is met by defining the mix of goods and services in the 'expenditure basket' according to consumer expenditure allocations. Different mixes or bundles of goods and services (expenditure baskets) may be defined for different consumer groups (for example high or low income groups, or rural or urban groups).

There is, however, a conflict between conditions (a) and (b) if the expenditure patterns of consumers change over time - as they do as a result of, for example, changing prices, changing tastes, changing technologies, and changing incomes (in growing economies). This conflict is addressed by periodically modifying the expenditure basket, with calculation of the value of both old and new expenditure baskets for transition years to allow calculation of a continuous CPI over longer periods despite changes in expenditure patterns.

We can explore how this affects the estimation of real prices by defining $t^{*}$ as a year when the expenditure basket is changed, with the new series CPI* . 
For years subsequent to $t^{*}$ (i.e. $\left.t>t^{*}\right)$,

$$
\mathrm{CPI}_{\mathrm{t}}^{*}=\left(\sum\left(\mathrm{P}_{\mathrm{jt}} \mathrm{W}_{\mathrm{jt}}\right) / \sum\left(\mathrm{P}_{\mathrm{jt}} \mathrm{W}_{\mathrm{jt}} \mathrm{t}^{*}\right)\right)\left(\sum\left(\mathrm{P}_{\mathrm{jt}} * \mathrm{~W}_{\mathrm{j} 0}\right) / \sum\left(\mathrm{P}_{\mathrm{j} 0} \mathrm{~W}_{\mathrm{j} 0}\right)\right)
$$

where $w_{j t^{*}}=P_{j t^{*}} Q_{j t^{*}} / \sum\left(P_{j t^{*}} Q_{j t^{*}}\right)$

$$
W_{j 0}=P_{j 0} Q_{j 0} / \sum\left(P_{j 0} Q_{j 0}\right)
$$

and $\mathrm{CPI}_{\mathrm{t}}{ }_{\mathrm{t}}$ is the $\mathrm{CPI}$ in year $\mathrm{t}$ relative to year 0 (calculated as $\mathrm{CPI}$ in year $\mathrm{t}$ relative to year $\mathrm{t}^{*}$ multiplied by CPI of $t^{*}$ relative to base year) with $t^{*}$ replacing $t=0$ in equations ( 2 ) and (3).

Inserting (6) and (7) into (5),

$$
\begin{aligned}
& C P I^{*}=\left(\sum \left(P_{j t}\left(P_{j t} Q_{j t^{*}} / \sum\left(P_{j t^{*}} Q_{j t^{*}}\right)\right) / \sum\left(P_{j t^{*}}\left(P_{j t^{*}} \mathrm{Q}_{j t^{*}} / \sum\left(P_{j t^{*}} \mathrm{Q}_{j t^{*}}\right)\right)\right) .\right.\right. \\
& \left(\sum\left(\mathrm{P}_{\mathrm{jt}}{ }^{*}\left(\mathrm{P}_{\mathrm{j} 0} \mathrm{Q}_{\mathrm{jo}} / \sum\left(\mathrm{P}_{\mathrm{j} 0} \mathrm{Q}_{\mathrm{j} 0}\right)\right) / \sum\left(\mathrm{P}_{\mathrm{j} 0} \mathrm{P}_{\mathrm{j} 0} \mathrm{Q}_{\mathrm{j} 0} / \sum\left(\mathrm{P}_{\mathrm{j} 0} \mathrm{Q}_{\mathrm{j} 0}\right)\right)\right)\right.
\end{aligned}
$$

and rearranging (8) gives

$$
C P I^{*}=\left(\sum\left(P_{j t}\left(P_{j t^{*}} \mathrm{Q}_{\mathrm{jt}}\right) / \sum\left(\mathrm{P}_{\mathrm{jt} t^{*}} \mathrm{Q}_{\mathrm{jt}}\right)\right) \cdot\left(\sum\left(\mathrm{P}_{\mathrm{jt}} \mathrm{P}_{\mathrm{j} 0} \mathrm{Q}_{\mathrm{j} 0}\right) / \sum\left(\mathrm{P}_{\mathrm{j} 0}{ }^{2} \mathrm{Q}_{\mathrm{j} 0}\right)\right)\right.
$$

We now examine the effects of changes in expenditure baskets on the $\mathrm{CPI}$ and on real food prices for people or economies with different income growth by considering their changing expenditures on goods and services $\mathrm{F}$ and $\mathrm{G}$ (as defined in the main text as goods and services with respectively low and high income and price elasticity ).

$\mathrm{CPI}$ in year $\mathrm{t}$ after a change in year $\mathrm{t}$ *in $^{\text {in }}$ the expenditure basket used in CPI calculation is given by

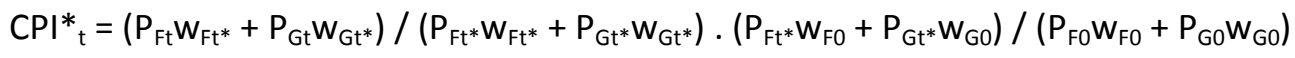

This allows us to explore how $\mathrm{CPI}^{*}$ varies for people or economies with (a) stagnant and (b) growing incomes. We consider a situation where all income groups have low income in year 0 , but the population then divides into a low income group $(\mathrm{L})$ who experience no growth in income through year $t^{*}$ to year $t$, and a high income group $(H)$ who experience high growth in income through year $t^{*}$ to year $t$. For the low income group there are no changes in expenditure basket and weights $\mathrm{w}_{\mathrm{F}}$ and $\mathrm{w}_{\mathrm{G}}$ in the calculation of $\mathrm{CPI}$, so

$C P I^{*}{ }_{\mathrm{Lt}}=\left(\mathrm{P}_{\mathrm{Ft}} \mathrm{W}_{\mathrm{FO}}+\mathrm{P}_{\mathrm{Gt}} \mathrm{W}_{\mathrm{G} 0}\right) /\left(\mathrm{P}_{\mathrm{Ft}} * \mathrm{~W}_{\mathrm{FO}}+\mathrm{P}_{\mathrm{Gt}} * \mathrm{~W}_{\mathrm{G} 0}\right) \cdot\left(\mathrm{P}_{\mathrm{Ft}} * \mathrm{~W}_{\mathrm{FO}}+\mathrm{P}_{\mathrm{Gt}} * \mathrm{~W}_{\mathrm{G} 0}\right) /\left(\mathrm{P}_{\mathrm{FO}} \mathrm{W}_{\mathrm{F} 0}+\mathrm{P}_{\mathrm{G} 0} \mathrm{~W}_{\mathrm{G} 0}\right)$

Rearranging, $C P I_{L t}^{*}=\left(P_{\mathrm{Ft}} \mathrm{W}_{\mathrm{F} 0}+\mathrm{P}_{\mathrm{Gt}} \mathrm{W}_{\mathrm{G} 0}\right) /\left(\mathrm{P}_{\mathrm{FO}} \mathrm{W}_{\mathrm{F} 0}+\mathrm{P}_{\mathrm{G} 0} \mathrm{~W}_{\mathrm{G} 0}\right)$

For the high income groups, however, the expenditure shares on $\mathrm{F}$ and $\mathrm{G}$ change over time (with decreases in relative expenditure on $\mathrm{F}$ and increases in relative expenditure on $\mathrm{G}$ ) so

$\mathrm{CPI}{ }_{\mathrm{Ht}}=\left(\mathrm{P}_{\mathrm{Ft}} \mathrm{W}_{\mathrm{HFt}}+\mathrm{P}_{\mathrm{Gt}} \mathrm{W}_{\mathrm{HGt}}\right) /\left(\mathrm{P}_{\mathrm{Ft}^{*}} \mathrm{~W}_{\mathrm{HFt}^{*}}+\mathrm{P}_{\mathrm{Gt}^{*}} \mathrm{~W}_{\mathrm{HGt}}\right) \cdot\left(\mathrm{P}_{\mathrm{Ft}} * \mathrm{~W}_{\mathrm{FO}}+\mathrm{P}_{\mathrm{Gt}} * \mathrm{~W}_{\mathrm{GO}}\right) /\left(\mathrm{P}_{\mathrm{FO}} \mathrm{W}_{\mathrm{FF}}+\mathrm{P}_{\mathrm{GO}} \mathrm{W}_{\mathrm{GO}}\right)$

With stagnant low incomes, as $\mathrm{w}_{\mathrm{G} 0}->>0$ and $\mathrm{w}_{\mathrm{F} 0}-->1$ then from (12)

$$
C P I^{* t}-->\left(P_{F t} W_{F O}+P_{G t} W_{G 0}\right) /\left(P_{F O} W_{F 0}+P_{G O} W_{G O}\right)-->=P_{F t} / P_{F 0}
$$


and with growing incomes, as $\mathrm{W}_{\mathrm{HFt}}-->0$ and $\mathrm{W}_{\mathrm{HFt}^{*}}-->0$ then from (13)

$$
\mathrm{CPI}_{\mathrm{Ht}}^{*}->=\left(\mathrm{P}_{\mathrm{Gt}} / \mathrm{P}_{\mathrm{Gt}^{*}}\right) \cdot\left(\mathrm{P}_{\mathrm{Ft}^{*}} / \mathrm{P}_{\mathrm{FO}}\right)
$$

and from (14) and (15)

$$
\left.\mathrm{CPI}_{\mathrm{Ht}} / \mathrm{CPI}_{\mathrm{Lt}}^{*}->\left(\left(\mathrm{P}_{\mathrm{Gt}} / \mathrm{P}_{\mathrm{Gt}^{*}}\right) \cdot\left(\mathrm{P}_{\mathrm{Ft}^{*}} / \mathrm{P}_{\mathrm{FO}}\right)\right) /\left(\mathrm{P}_{\mathrm{Ft}} / \mathrm{P}_{\mathrm{Fo}}\right)\right)=\left(\mathrm{P}_{\mathrm{Gt}} / \mathrm{P}_{\mathrm{Gt}^{*}}\right) \cdot\left(\mathrm{P}_{\mathrm{Ft}^{*}} / \mathrm{P}_{\mathrm{Ft}}\right)
$$

From (16), $\quad \mathrm{CPI}^{*}{ }_{\mathrm{Ht}}>\mathrm{CPI}_{\mathrm{Lt}}{ }_{\mathrm{Lt}}$ if $\left(\mathrm{P}_{\mathrm{Gt}} / \mathrm{P}_{\mathrm{Gt}^{*}}\right)>\left(\mathrm{P}_{\mathrm{Ft}} / \mathrm{P}_{\mathrm{Ft}^{*}}\right)$

(17) states the intuitively obvious condition that the CPI for the higher income group will be higher than the CPI for the lower income group if the rate of increase of prices for $\mathrm{G}$ is greater than the rate of increase of prices for $F$.

The rate of increases of prices is broadly dependent upon the ratio of increasing demand to increasing productivity. Since demand for $F$ is income inelastic and demand for $\mathrm{G}$ is income elastic, the rate of increase of demand for $G$ will be higher than the rate of increase of demand for $F$ as the incomes of the higher income group grow. The rate of increase of prices for $\mathrm{G}$ will therefore be greater than the rate of increase of prices for $F$ unless productivity growth across all $G$ is sufficiently higher than across $F$ to more than compensate for the differential growth in demand for $G$. $A$ number of studies report higher rates of productivity growth in agriculture than in other sectors across both developed and developing countries and groups of countries (see for example Martin and Mitra, 2001; Bernard and Jones. 1996 ). Martin and Mitra also discuss modelling evidence of the need for agricultural productivity growth to allow falling agricultural prices ${ }^{19}$.

\section{References}

Banse, M., P. Nowicki, et al. (2008). Why are current world food prices so high? Report 2008-040, LEI Wageningen UR: 31pp., fig., tab.

Bernard, A. and C. Jones (1996). "Productivity Growth Across Industries And Countries: Time Series Theory And Evidence." Review of Economics and Statistics 58(1): 135-146. .

Blisard, N., D. Smallwood, et al. (1999). Food Cost Indexes for Low-Income Households and the General Population. . Food and Rural Economics Division, Economic Research Service, . Technical Bulletin Number 1872. Washington D.C. , U.S. Department of Agriculture. .

Crawford, M. and S. Katz (2009). CPI Detailed Report: Data for December 2008. Washington DC, Bureau of Labour Statistics.

David, P. A. and P. Solar (1977). A Bicentenary Contribution to the History of the Cost of Living in America. Research in Economic History. Greenwich, JAI Press, Inc. 2: 1-80.

Deininger, K. and D. Byerlee (2011). Rising global interest in farmland : can it yield sustainable and equitable benefits? Washington D.C., World Bank.

Easterling, W. E., P. K. Aggarwal, et al. (2007). Food, fibre and forest products. . Climate Change 2007: Impacts, Adaptation and Vulnerability. Contribution of Working Group II to the Fourth Assessment Report of the Intergovernmental Panel on Climate Change. M. L. Parry, O. F.

\footnotetext{
${ }^{19}$ Of course not all agricultural products have low income and price elasticities as discussed above, but the sector as a whole does generally have these characteristics.
} 
Canziani, J. P. Palutikof, P. J. van der Linden and C. E. Hanson. Cambridge, UK, Cambridge University Press: 273-313.

Evans, A. (2009). The Feeding of the Nine Billion: Global Food Security for the 21st Century. $\underline{A}$ Chatham House Report.

FAO (2009). The state of agricultural commodity markets 2009: High food prices and the food crisis experiences and lessons learned. Rome, Food and Agricultural Organisation of the Unite Nations.

Financial Times (2010). Price increases fuel fears of food 'crises'. Financial Times. London. 15 June 2010.

Financial Times (2011). FAO draws comfort at lack of food riots. Financial Times. London. 5 January 2011

Godfray, H. C. J., J. R. Beddington, et al. (2010a). "Food Security: The Challenge of Feeding 9 Billion People." Science 327 812-818.

Godfray, H. C. J., I. R. Crute, L. Haddad, D. Lawrence, J. F. Muir, N. Nisbet, J. Pretty, S. Robinson, C. Toulmin and R. Whiteley (2010b). "The future of the global food system." Phil. Trans. R. Soc. B 365: 2769-2777.

Headey, D. and S. Fan (2010). Reflections on the global food crisis: how did it happen? how has it hurt? and how can we prevent the next one? IFPRI Research monograph 165. Washington D.C., International Food Policy Research Institute: 122.

Hertel, T. W., K. Anderson, et al. (2000). Agriculture and Non-Agricultural Liberalization in the Millennium Round. Policy Discussion Paper No. 0016 Centre for International Economic Studies, University of Adelaide

IMF (2010). International Finance Statistics.

Jensen, R. and N. Miller (2008). "Giffen behavior and subsistence consumption. ." American Economic Review 98(4): 1553-1577.

Johnston, B. F. and J. W. Mellor (1961). "The role of agriculture in economic development." The American Economic Review 51(4): 566-593.

Kaplinsky, R. (2006). "Revisiting the Revisited Terms of Trade: Will China Make a Difference?" World Development 34(6): 981-995.

King, J. (1976). The consumer price index: the measure of poverty. Technical paper 7, Department of health, education and welfare.

Koning, M. and M. K. van Ittersum (2009). "Will the world have enough to eat?" Current Opinion in Environmental Sustainability 1: 1-6.

Lipton, M. (1986). "Seasonality and Ultrapoverty." IDS Bulletin 17(3).

Martin, W. and D. Mitra (2001). "Productivity Growth and Convergence in Agriculture versus Manufacturing." Economic Development and Cultural Change 49(2): 403-422.

Murphy, E. and E. Garvey (2004). A Consumer Price Index for Low-Income Households in Ireland (1989-2001). Combat Poverty Agency, Working Paper 04/03.

Nelson, C. C., M. Rosegrant, et al. (2009). Climate Change: Impact on Agriculture and Costs of Adaptation. Food Policy Report. Washington D.C., International Food Policy Research Institute.

OECD (2008). Rising Food Prices: casues and consequences. Paris, Organisation for Economic Cooperation and Development OECD).

OECD-FAO (2010). OECD-FAO Agricultural Outlook 2010-2019. Paris, OECD.

Piesse, J. and C. Thirtle (2009). "Three bubbles and a panic: An explanatory review of recent food 
commodity price events." Food Policy 34: 119-129.

Pike, R., C. Marks, et al. (2008). "Measuring UK inflation." Economic \& Labour Market Review 2(9): 18-25.

Poverty Reduction and Equity Group (2010). Food Price Watch February 2010. Washington DC, PREM, World Bank.

Poverty Reduction and Equity Group (2010). Food Price Watch May 2010. Washington DC, PREM, World Bank.

Raihin, S. (2009). Study on Impact of Food Price Rise on School Enrolment and Dropout in the Poor and Vulnerable Households in Selected Areas of Bangladesh. . Report commissioned by DFID, Dhaka.

The Economist (2009). How to feed the world. The Economist: 13.

The Economist (2010). Dare to grow more. The Economist: 72.

Toye, J. (2009). "Development with dearer food: can the invisible hand guide us?" Journal of International Development 21: 757-764.

UNCTAD (2010). UNCTAD Handbook of statistics 2009. Geneva, UNCTAD.

US Bureau of Labor Statistics (2010). Consumer Price Index, All Urban Consumers - (CPI-U), U.S. city average, All items, 1982-84=100, US Department of Labor, Bureau of Labor Statistics.

USDA (2010). Wheat Data: Yearbook Tables, United States Department of Agriculture.

Von Braun, J. (2008). Food and financial crises: implications for agriculture and the poor. Food Policy Report. Washington DC, Food Policy Research Institute.

World Bank (2010). World Development Indicators.

World Summit on Food Security (2009). Declaration of the World Summit on Food Security. WSFS 2009/2. Rome, FAO. 